\title{
Chemical analysis: sources of error
}

\author{
By P. J. ButTery and D. J. A. Cole, University of Nottingham, School of \\ Agriculture, Sutton Bonington, Loughborough, Leicestershire $L E_{12}{ }_{5} R D$
}

The analysis of samples taken from experiments in nutrition research presents a multitude of problems and in the space available it would be impossible to cover the entire field. Instead a selection of the considerations necessary to reduce the effect of error in chemical analyses is given. The analysis of amino acids and determination of the composition of the digesta entering the duodenum of the ruminant are used as examples for more detailed discussion.

\section{Some consequences of analytical error}

Animal experiments are commonly used for establishing energy and nutrient requirements and for evaluating feedstuffs to meet these requirements. The balance experiment is an example of a technique which is frequently used and involves considerable chemical analysis.

The errors in any conclusions regarding, for example, the energy and nitrogen nutrition of the animal will be related to the quantitative contribution of that part of the balance in which an initial error might occur. In an experiment with pigs (D. J. A. Cole, unpublished results) the contribution of the feed, faeces and urine to the energy balance was $49 \cdot 2 \mathrm{I}, 9 \cdot 83$ and $\mathrm{I} \cdot 36 \mathrm{MJ} / \mathrm{d}$ respectively while the contribution to the $\mathrm{N}$ balance was $88.7,14.1$ and $53.7 \mathrm{~g} \mathrm{~N} / \mathrm{d}$ respectively. The apparent metabolizable energy (ME) content of the diet was calculated to be $15.56 \mathrm{MJ} / \mathrm{d}$. The consequences of underestimating energy by as much as $10 \%$ in either the feed, faeces or urine would be errors of $2.01,0.40$ and $0.06 \mathrm{MJ} \mathrm{ME} / \mathrm{kg}$ respectively. Similarly, the errors in $\mathrm{N}$ retention are related to the magnitude of the component in which they occurred. $N$ retention was calculated to be $21.0 \mathrm{~g} / \mathrm{d}$ and a $10 \%$ underestimation of $\mathrm{N}$ in the feed, faeces or urine would result in errors of $9 \cdot 0,1 \cdot 3$ and $5.3 \mathrm{~g} / \mathrm{d}$.

Thus a $10 \%$ error in the energy determination of urine would result in an error of $0.39 \%$ in the ME value of the diet. An error of similar magnitude in the $\mathrm{N}$ determination of the urine, however, would result in a $25 \%$ error in $\mathrm{N}$ retention. This illustrates the need for the experimenter to give careful consideration to the use he is making of chemical analyses and the precision which he demands from them.

\section{Sources of error}

\section{Samples from balance trials}

The contribution made by precise and careful chemical analysis can only be within the limits imposed by the sample itself. Consequently every effort should be 
made to minimize these errors before the analysis begins. The sources of error at this stage are many and the following serve as examples.

Pre-sampling losses can occur between the voiding of faeces and urine and collection. Losses of $\mathrm{N}$ from faeces tend to be small, e.g. up to $2 \%$ in sheep faeces at room temperatures (Waite, Johnston \& Armstrong, 1964) and attempts to reduce these losses by collecting every $6 \mathrm{~h}$ rather than every $24 \mathrm{~h}$ were ineffective in the sheep, rabbit and guinea pig. Similarly the use of preservatives was also ineffective (Sharkey, 1970). In contrast losses of volatile ammonia from urine can be considerable but the use of acid is effective in reducing such losses. For example Martin (1966) reported that $6.75 \%$ of the $\mathrm{N}$ in calf urine was lost at $30^{\circ}$ and $\mathrm{pH}$ $7.5-8.5$ but the addition of $18 \mathrm{ml} 9 \mathrm{M}$-sulphuric acid/l urine to keep the $\mathrm{pH}$ below 2.0 reduced losses to $0.02 \%$. The same author has indicated the importance of dermal losses and errors in collection.

Losses of energy and $\mathrm{N}$ can also occur in the preparation and storage of the sample. Thus, fresh or freeze-dried samples are preferable to oven-dried samples. Sharkey (1970) has reported N contents of faecal samples dried at $80^{\circ}$ or stored at $-20^{\circ}$ of 13.9 and $16.0,11.7$ and 12.2 and 14.3 and $15.0 \mathrm{mg} / \mathrm{g}$ dry matter for the guinea pig, sheep and rabbit respectively.

\section{Amino acid analysis}

Some marked errors can be introduced during the hydrolysis of protein and the major problems occur with cysteine (cystine), methionine and tryptophan. Cysteine is oxidized to a variable degree and it is usual to ensure that complete oxidation to cysteic acid takes place. Of the many techniques available the simplest, and therefore the least likely to suffer from 'operator error', is hydrolysis in the presence of a small amount of dimethyl sulphoxide (Spencer \& Wold, 1969). Often an oxidation procedure is also used for the analysis of methionine (e.g. Bidmead \& Ley, 1958). The product of oxidation, methionine sulphone, can be difficult to separate from aspartic acid (Lazarus, 1976) and this can cause error. This is best overcome by hydrolysis of the protein in the presence of a large volume of acid, purging the system with $\mathrm{N}$ and then assaying for free methionine. Tryptophan is destroyed by hydrolysis with 6 M-hydrochloric acid and it is conventional to subject the protein to alkaline hydrolysis. Even so, losses of tryptophan do occur but can be corrected by assessing tryptophan recovery by adding an authentic standard of tryptophan. The use of free tryptophan rather than peptide-bound tryptophan may in itself introduce bias. Following discussion of the results of a collaborative trial in tryptophan analysis of feeding-stuffs, in which the methods of Spies \& Chambers (1949) and Miller (1967) were evaluated, Westgarth \& Williams (1974) state 'that only when workers have familiarized themselves with a method did they obtain consistent results'. Familiarity with various techniques is probably one of the most important factors when attempting to reduce analytical bias.

Another analytical procedure which is subjected to much discussion, not only from a chemical point of view, but also from consideration of the biological 
significance of the chemical results, is the determination of available lysine. For a detailed discussion of this area the several excellent reviews by Carpenter (e.g. Carpenter, 1974) are recommended.

In attempting to evaluate or establish a technique it is essential to have a standard. Two approaches are available. Firstly, to compare results obtained for a particular feedstuff with results obtained by other workers using if possible the same batch. This is where collaborative trials are so useful. Secondly, some useful information can be gained using a protein of known amino acid composition, e.g. lysozyme (Jolles, I 967). However, the use of a pure protein standard can lead to an optimistic estimate of the errors associated with an analytical technique unless the standard is used to test recoveries of amino acids following its addition to a feedstuff. A possible alternative, applicable to most systems, is to carry out the hydrolysis in the presence of starch.

The almost blind acceptance of the results of automatic amino acid analysis procedures can introduce bias. The majority of techniques owe their origin to systems developed for pure proteins or simple physiological fluids and are not always suitable for the complex mixtures often used in experimentation with large animals. For example, chromatograms of sheep plasma run on most physiological systems (e.g. Atkin \& Ferdinand, 1970) yield a symmetrical peak apparently of lysine, however this is a double peak containing appreciable quantities of $N$ methyl-lysine and requires special chromatographic systems to ensure resolution (Beckerton, Buttery, Bailey \& Bolton, 1974). This problem illustrates the desirability of ensuring that some of the samples from a system with which the laboratory is not familiar are analysed on at least two quite distinct systems.

Much of the bias introduced into experiments involving amino acids probably comes from constraints imposed by the difficulty of being able to analyse sufficient samples and it is for this reason that encouragement should be given to the development of cheaper techniques of analysis, e.g. gas-liquid chromatography, and for the development of specific assays for the nutritionally important amino acids.

\section{Assessment of microbial protein synthesis in the rumen}

Most of the in vivo techniques employ a marker which is either incorporated into, or synthesized by, the rumen micro-organisms. Labelled markers include ${ }^{35} \mathrm{~S}$, the most common, ${ }^{15} \mathrm{~N}$ or for very specific purposes ${ }^{32} \mathrm{P}$. Metabolites synthesized by the microbial fraction can also be exploited, e.g. diaminopimelic acid, aminoethyl-phosphonic acid, ribonucleic acid. It is also possible to utilize the differences in the amino acid composition of the individual components of the digesta. All techniques require the isolation of a representative sample of the microbial population, usually using differential centrifugation. This in itself presents problems, often greater than those associated with the subsequent chemical analysis.

${ }^{35} S$ incorporation into microbial protein. This technique depends on the labelling of the microbial fraction with ${ }^{35} \mathrm{~S}$, usually $\mathrm{SO}_{4}{ }^{2-}$ and then the 
determination of the dilution of the specific activity of a sulphur component in both the digesta and the microbial fraction. Both cysteine and methionine have been used. Cysteine is usually oxidized to cysteic acid (Leibholz, 1972). Beever, Harrison, Thomson, Cammell \& Osbourn (1974) determined the specific activity of methionine by oxidizing it with performic acid. However, in order to determine the specific activity of the methionine sulphone it was necessary to employ two chromatographic steps to separate the labelled sulphone from other sulphur compounds. It is possible to simplify the technique by isolating methionine itself (Ling \& Buttery, 1977). The analytical methods adopted by others e.g. Hume (1974) in which the specific activity of the total sulphur fraction is determined are much simpler than those involving the isolation of amino acids. However, the absorption of labelled sulphur onto the bacterial fraction may potentially introduce an error which makes it essential to ensure that the isolated fraction is washed well.

It has been suggested (Beever et al. 1974) that direct incorporation of dietary methionine into the microbial fraction may introduce an error. However, it is difficult to accept that this would be serious since it is only a ratio of the specific activity of the sulphur in the microbial fraction and in the digesta fraction which is being measured. It is worth considering that methionine is more likely to be directly incorporated into protozoal protein and that the ratio of protozoa to bacteria may be lower in the isolated microbial fraction than that in the rumen. If this were the case, the specific activity of the microbial fraction would be overestimated with a consequent reduction in the estimated contribution of microbial protein to the digesta. However, the results of Beever et al. (1974) indicate that protozoal and bacterial specific activities are similar provided the infusion of ${ }^{33} \mathrm{SO}_{4}$ is carried on for long enough.

The technique also suffers from a failure to allow for the effect of endogenous protein reactions, but as pointed out by Beever et al. (1974) this is unlikely to be serious since animals given diets devoid of protein give digesta in which the specific activity of the microbial fraction is almost identical to that of the digesta itself. When using the technique it is also necessary to correct for differences in the methionine or cysteine content of the various proteins in the digesta. Beever et al. (1974) suggest that this should be done from a knowledge of the methionine content of the feed and the microbial fraction. However, as pointed out by Ling \& Buttery (1977) it may be better to use the methionine content of the microbial fraction and the digesta since this is more likely to allow for the differential breakdown of the individual protein found in the feed.

${ }^{15} \mathrm{~N}$ incorporation. The one great advantage of this technique is that it deals directly with the $\mathrm{N}$; but as a routine technique for assessing microbial protein synthesis it is too complicated. However, it has yielded some excellent results on ruminant $N$ metabolism (see Nolan, Norton \& Leng, 1976).

Diaminopimelic acid (DAPA). This amino acid is confined to the cell walls of certain bacteria, although it is absent from some species (e.g. Work, 1955). It is important to remember that it is not a constituent of bacterial protein. Thus any 
change in the ratio of bacterial protein to bacterial cell wall, e.g. lysis of cells between the rumen and the digesta sampling site, may introduce bias. Another potential problem of this technique is the possibility of metabolism of DAPA prior to the digesta sampling site. It is essential that all DAPA released from lysed bacteria in the rumen is catabolized before the digesta reaches the sampling site. Findings on which to discuss these points are sparse (Ling \& Buttery, 1977).

The main objection to the use of DAPA is that its concentration varies from species to species (Work \& Dewey, 1953). This means that the ratio, DAPA:N of the bacterial fraction must be determined for each experimental situation. Perhaps the major advantage of the DAPA technique is that it is relatively easy to assay since it shares with proline the property of giving a yellow colour with acid ninhydrin. This has enabled simple ion-exchange chromatographic systems to be developed (Hutton, Bailey \& Annison, r971).

For the technique to give accurate results it is essential to ensure that the diet contains no DAPA and this would appear to be the case (Synge, 1953) although traces can be detected in protozoa, probably due to the engulfment of bacteria (Czerkawski, 1974). The DAPA technique only gives an indication of bacterial protein flow, however protozoal protein flow can be assessed using aminoethylphosphonic acid (AEPA).

Aminoethylphosphonic acid (AEPA). This amino acid is found in the lipid fraction of protozoa and presents one of the few methods of determining the protozoal contribution to duodenal protein flow. Unfortunately it is difficult to assay. Although Abou Akkada, Messmer, Fina \& Bartley (1968) determined the phosphate content of AEPA by a mixture of paper and column chromatography, the method is time consuming and tedious. Ibrahim, Ingalls \& Bragg (1970) reported a column chromatographic system using ninhydrin for detection, but they reported an erroneous elution time $(\mathrm{I} 85 \mathrm{~min})$, subsequently corrected to $27 \mathrm{~min}$ (Anon, 1973). Czerkawski (1974) and El-Shazly, Nour \& Abou Akkada (r975), again using column chromatography, estimated AEPA by determining phosphate following acid hydrolysis. Ling \& Buttery (1977) developed a satisfactory system (similar to that of Hagemeister, 1975) using cation-exchange chromatography on a conventional automatic amino acid analyser in which AEPA was eluted towards the start of the chromatogram.

It is essential with these techniques to use relatively concentrated hydrolysates to detect the AEPA, especially in the digesta fraction. Although it has been reported that AEPA was absent from feed (Abou Akkada et al. 1968) the use of concentrated feed hydrolysates yielded a peak in the position of AEPA (Ling \& Buttery, 1977). This peak was assumed to be AEPA following investigation of its chromatographic properties in several systems. AEPA was also found in bacteria (see Fig. 1), an observation also reported by Czerkawski (1974) but contrary to the findings of Abou Akkada et al. (1968). This technique therefore requires careful use and due to the large corrections required to allow for dietary AEPA etc. might be considered far from satisfactory. 


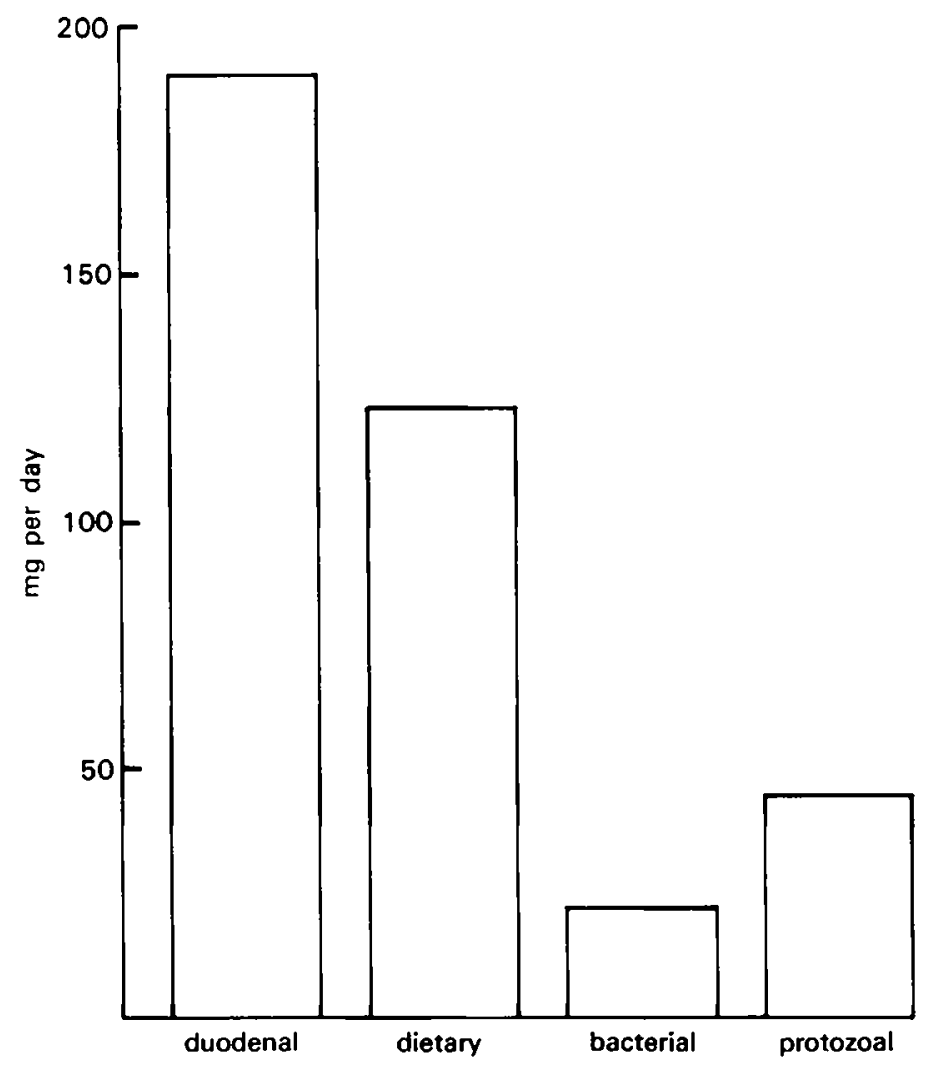

Fig. 1. The origin of the amino-thylphosphonic acid present in the digesta of sheep fed a fishmeat-barley diet. The results are the mean of three sheep. For details see Ling \& Buttery, 1977.

Ribonucleic acid. This technique relies on the assumption that all dietary nucleic acid is broken down in the rumen and the nucleic acid leaving the rumen is of microbial origin. There is some doubt as to whether this is entirely true and microbial protein flow may be over estimated. This may be particularly important when large portions of the dietary protein and nucleic acid have been rendered insoluble by exposure to heat or chemical treatment. There are also problems associated with the difference in RNA content between bacteria and protozoa. However, the advantage of this technique is that it does not require expensive apparatus. Although the method described by McAllan \& Smith (1969) suffers from being very tedious and good results are dependent upon obtaining a satisfactory batch of resin, it has yielded much good data. In order to overcome the analytical problems Ling \& Buttery (1976) adapted the much simpler method of Guinn (1966) so that it was suitable for rumen digesta samples. The method relies on extraction of the nucleic acid fraction and subsequent assay of the RNA using orcinol. Although the orcinol reaction is interfered with by the presence of DNA, this interference is minimal compared with the errors that would appear to be associated with chromatographic separation of the nucleic acid. In addition, the 
effect of DNA could be corrected by determining the DNA content using the diphenylamine reaction.

Amino acid profiles. The differences in the amino acid content of the proteins reaching the duodenum has been exploited by Evans, Axford \& Offer (1975). They report the use of a computer program which will calculate composition of the duodenal digesta when given the complete amino acid profiles of the diet, the digesta, the protozoa and bacteria together with estimates of the contribution and composition of the endogenous protein. This method shows promise and gives the most complete picture of the techniques available. Since it relies on the analysis of several different constituents (amino acids) it might be expected, with more development, to yield answers with the least bias. However, it does suffer from problems common to most other techniques associated with the estimation of the contribution of endogenous proteins together with problems associated with the effects of the differential degradation of individual proteins found within each dietary constituent. If the report (Bergen, Purser \& Cline, 1967) that the amino acid composition of different species of bacteria is almost identical is valid then the method has the advantage that the bacterial isolate is representative.

Over-all comments. The problem of assessing the bias of each technique is difficult, since no absolute standards are available. Following a comparison of the ${ }^{35}$ S, DAPA, RNA and AEPA techniques, Ling \& Buttery (1977) concluded that each technique had its own special merits but the best over-all picture of microbial activity was probably given using the ${ }^{35} \mathrm{~S}$ technique, although the RNA method is very attractive since it is much less complex and is more rapid.

\section{Conclusions}

Reduction of the effects of error introduced during chemical analysis requires a detailed consideration not only of the techniques used but also of the precision required in each step of the procedure.

The authors wish to acknowledge the help of Dr J. R. Ling and J. Wiseman with the preparation of the manuscript although responsibility for its imperfection is naturally that of the authors.

\section{REFERENCES}

Abou Akkada, A. R., Messmer, D. A., Fina, L. R. \& Bartley, E. E. (1968). F. Dairy Sci. $51,78$. Anon (1973). Can. F. Anim. Sci. 53, 761.

Atkin, G. E. \& Ferdinand, W. (1970). Analyt. Biochem. 38, 313.

Beckerton, A., Buttery, P. J., Bailey, F. J. \& Bolton, N. (1974). F. Chromat. 104, 170.

Beever, D. E., Harrison, D. G., Thomson, D. J., Cammell, S. B. \& Osbourn, D. F. (1974). Br. F. Nutr. 32, 99 .

Bidmead, D. S. \& Ley, F. J. (1958). Biochim. Biophys. Acta. 29, 562.

Carpenter, K. J. (1974). In University of Nottingham Nutrition Conference for Feed Manufacturers, Vol. 8. [H. Swan and D. Lewis, editors]. London: Butterworths.

Czerkawski, J. W. (1974). F. Sci. Fd. Agric. 25, 45.

El-Shazley, K., Nour, A. M. \& Abou Aktada (1975). Analyst 100, 263.

Evans, R. A., Axford, R. F. E. \& Offer, N. W. (1975). Proc. Nutr. Soc. 30, 40 A.

Guinn, G. (1966). Plant Physiol. 41, 689. 
Hagemeister, H. (1975). Kieler milchw. ForschBer. 27, 347.

Hutton, K., Bailey, F. J. \& Annison, E. F. (1971). Br. Y. Nutr. 25, 165.

Ibrahim, E. A., Ingalls, J. R. \& Bragg, D. B. (1970). Can. F. Anim. Sci. 50, 397.

Jolles, P. (1967). Proc. R. Soc. B. 167, 350.

Hume, I. D. (1974). Aust. F. agric. Res. 25, 155.

Lazarus, W. (1976). F. Chromat. I16, 237.

Leibholz, J. (1972). Aust. F. agric. Res. 23, 1073.

Ling, J. R. \& Buttery, P. J. (1976). Proc. Nutr. Soc. 35, 39A.

Ling, J. R. \& Buttery, P. J. (1977). Br. Y. Nutr. (In the Press).

McAllan, A. B. \& Smith, R. H. (1969). Br. f. Nutr. 23, 671.

Martin, A. K. (1966). Br. J. Nutr. 20, 325.

Miller, E. L. (1967). f. Sci. Fd. Agric. 18, 381 .

Nolan, J. V., Norton, B. W. \& Leng, R. A. (1976). Br. F. Nutr. 35, 127.

Purser, D. B. \& Buechler, J. M. (1967). F. Dairy Sci. 49, 81.

Sharkey, M. J. (1970). F. Br. Grassld. Soc. 25, 289.

Spencer, R. L. \& Wold, F. (1969). Analyt. Biochem. 32, 185.

Spies, J. R. \& Chambers, D. C. (1949). Analyt. Chem. 21, 1249.

Synge, R. L. M. (1953). F. Gen. Microbiol. 9, 407.

Waite, R., Johnston, M. J. \& Armstrong, D. G. (1964). F. agric. Sci., Camb. 62, 391.

Westgarth, D. R. \& Williams, A. P. (1974). F. Sci. Fd. Agric. 18, 381 .

Work, E. (1955). Biochim. biophys. Acta $17,410$.

Work, E. \& Dewey, D. L. (1953). f. Gen. Microbiol. 9, 394. 